\title{
The role of international competences in increasing graduates' access to the labor market
}

\author{
Lavinia Cornelia BUTUM \\ The Bucharest University of Economic Studies, Bucharest, Romania \\ butum_lavinia@yahoo.com
}

\begin{abstract}
The transition from student to employee status has become an important issue for labor market analysts, students and universities. Literature recognizes that the international experience represents a successful factor for future employability. In this regard, a new curricular model should include international competences in order to build the qualifications required by the global labor market. A recent study (Stan, Butum \& Zodieru, 2016) highlighted the importance of youngsters' professional training upon graduation and the crucial role of collaboration between universities, companies and governments (through education policies) in increasing graduates' accessibility to well - paid jobs and in developing an entrepreneurial career. The same study provides the results of a qualitative research that leads to the conclusion that most Romanian students have the capacity to obtain the desired job if they can swiftly gain the soft skills required by companies. It is also mentioned that the labor market has increased the demand for international competences and practical skills in recent years. The purpose of this article is to analyze the dynamics of Romanian and European students' feedback on their universities. Beginning with the analysis of soft skills needed for the labor market and their appreciation as perceived by students, the study will examine the dynamics of students' appreciation on international experience and other work activities that ensure the achievement of international competences and reduce the time for obtaining a job. Afterward, the paper will analyze students' career priorities and students' perception of university performance in providing practical and international skills needed for the labor market. The analysis will include 3-year statistic data from Trendence Graduate Barometer regarding Romanian students' perception. The conclusions will show the dynamic of students' expectations on provided skills and the connection with their career priorities. Furthermore, the main results of this study will represent a basis for future research in designing a guide for developing the internationalized curriculum, as well as for a future analysis of the international competences needed by students when searching for a well-paid job.
\end{abstract}

Keywords: high- skilled employees, higher education, international mobility, international competences, labour market, learning process.

\section{Introduction}

This paper approaches the competences from an international perspective. First, the literature review chapter will examine the international soft skills required by the labor market and will then analyze the connections between international experience and graduates' career opportunities.

The article will highlight the dynamics of Romanian and other European students' appreciation for soft skills provided by their university and will compare the university performance in terms of importance versus satisfaction as perceived by students. Also, the analysis of students' appreciation for career opportunities and international experience defined as work, study or voluntary activities in a foreign country, will show the increase in demand for international competences, in view of obtaining a job in an international environment. 


\section{Literature review}

\section{International soft skills for the labor market}

A definition of soft skills mentioned by Oxford Dictionary is related to "Personal attributes that enable someone to interact effectively and harmoniously with other people". In other words, these abilities open the path for the other competences (technical or professional competences) needed in everyday work life. While hard skills represent the technical expertise and knowledge needed for a job and are easily gained by achieving educational curricula, soft skills need special attention. Traditionally, universities have focused more on hard skills. Content knowledge and critical thinking are usually developed through curriculum content and these are also known as cognitive skills. A recent study (Ortega Goodspeed, 2016) has focused more on aspects regarding the non - cognitive skills or soft skills. Even if it is hard to categorize and to establish the relative importance of these skills, some authors have frame-worked the skills according to the competences in their field of activity. Thus, from a psychological point of view, (Heckman and Kautz, 2012; Santos and Primi, 2014) cited in Ortega Goodspeed article, frame-worked the skills into a Big Five categories and characteristics: openness to new experiences, conscientiousness, extraversion, agreeableness and emotional stability. Economists highlighted different frameworks focusing more on business skills, communication, persuasiveness, teamwork abilities and flexibility. In a nutshell, the soft skills are considered inter-personal abilities and they could be achieved in universities or towards coaching, training and specialized professional training (Stan, Butum \& Zodieru, 2016). The study also mentioned that employers' opinions regarding interpersonal, international and practical abilities presented by young graduates differ depending on the profile of the company. Thus, business - oriented companies put more emphasis on interpersonal and international abilities when recruiting young graduates.

Since interpersonal abilities are essential in today's workplace, these skills should be viewed as a long - term investment in human capital. Some studies (Robles, 2012) and (Ortega Goodspeed, 2016) suggest that soft skills should be integrated as part of curricula in order to be learned by students before becoming employees. The purpose is to create an efficient graduate that has the ability to work and adapt easily in different and complex projects or work teams. In his study, Robles identifies the top 10 soft skills as perceived by business executives. On the one hand, some identified skills are moral and ethical skills, such as integrity, courtesy, professionalism, work ethic or responsibility. On the other hand, the study identifies skills that are related to the ability to work and communicate in multidisciplinary teams, such as social skills, positive attitude, teamwork, communication and flexibility.

Not only occasionally, soft skills are seen as a long - term investment in growing human capital. In the first place, for both students and employers, the achievement of the right skills represents a good opportunity for future profits - in terms of wages and work productivity. In other words, this represents a win-win situation for the future graduates and employers. Secondly, once achieved, the soft skills could be developed after graduation. Usually, multinational companies provide short-term courses for their employee in order to teach their specific methodologies and work techniques.

The importance of both hard skills and soft skills is recognized especially in complex projects and multinational companies, where employees have to manage complex situations. The term of complex projects is related to "many different people with different skills", "variety of people in terms of skills and experience", multidisciplinary and multinational teams. In these cases, the hard skills are important for planning, controlling and achieving the goals, and soft skills are important for tasks 
optimization (Azim et al., 2010, p. 396). The results of the study highlighted the importance of soft skills required to manage "people" in different and multidisciplinary teams "... the real success comes from knowing how to get things done through others" (Azim et al., 2010, p. 398).

Global competences are part of soft skills and generally, are related to workforce competences recognized internationally. OECD defines global competences as "the capacity to analyze global and intercultural issues critically and from multiple perspectives, to understand how differences affect perceptions, judgments, and ideas of self and others, and to engage in open, appropriate and effective interactions with others from different backgrounds on the basis of a shared respect for human dignity" (OECD, 2016). Moreover, the study mentions some key abilities related to global competences such as: the ability to communicate in more than one language, to communicate appropriately with people from other cultures or countries, the capacity to analyze and think critically in order to take a decision on everyday work issues in multinational companies.

\section{International experience and graduates' opportunities}

Universities have increased their participation in international activities as a consequence of increasing demand for curriculum enrichment through international studies and foreign language specialization. Thus, international programs provide international and cross-cultural perspectives for students.

In Europe, EU authorities have promoted the academic internationalization to sustain the economic and political integration and to maintain economic competitiveness (Altbach \& Knight, 2007). European Commission's policy emphasizes the role of higher education in provisioning young graduates with core transferable competences needed to succeed in high - skill occupations (Eurydice Report, 2014). Moreover, the European policies regarding higher education internationalization encourage students' mobility in order to ensure the increase of students' ability to work, communicate and participate in complex projects in any country in Europe and to develop students' European identity (Brooks \& Waters, 2011).

Even if the work and employment conditions in Europe still depend on national patterns, changes related to global labor market development have increased international work opportunities, in the late years (Enders \& Weert, 2009). The global mobility of people and knowledge has major implications for students, universities and employers.

For students, the technological and economic changes and global mobility represent a new and valuable opportunity. Since they are taking part in a growing global process in the distribution and dissemination of knowledge, they have infinitely more chances to gain international skills during their university courses. The introduction of international content into curricula is a consequence of the increasing need to obtain international skills for the workforce in the global economic marketplace. Also, the encouragement of volunteering as an extracurricular activity during higher education programs has the direct implication on skills development and future employability. First of all, volunteering has strong implications in establishing a close connection with local and international communities and second, helps the students to gain soft skills for the rapid integration into the labor market upon graduation (Matthews et al., 2009). In addition, student's involvement in mobility projects is seen as an opportunity to achieve valuable skills resulting from the interaction with other cultures and thus is seen as a successful factor for future employability (Nicolescu \& Galalae, 2013). 
Universities have an important role in ensuring the students' access to international mobility. It's their responsibility to let students engage in experiences that facilitate international and intercultural relations, as well as cultural practice in an international environment (OECD, 2016). Lately, the European policies regarding student's mobility, e.g. ERASMUS+ programs, have provided opportunities for students, helping them to develop and share knowledge, and experience in institutions and organizations in different countries. Even more, the EU Youth Strategy sets out a framework for cooperation covering years 2010-2018. The main objectives of that strategy are related to providing equal opportunities for young people and encouraging young people to participate more actively in society (EC Youth, 2014). When collaborations between universities are successful, usually the number of ingoing and outgoing students is increasing. Students' choice to complete their studies abroad comes with the choice of renowned universities. The quality of educational services in higher education is measured periodically through the importance and the utility of different aspects of the educational process as seen by students. Students' appreciation for achieved skills upon graduation varies and depends mostly on their utility at the workplace. Studies conducted in Romania for ensuring the measurement of quality in terms of requirements and expectations of the multiple educational stakeholders have traced some directions and recommendations at the institutional level (Nicolescu, 2011; Nicolescu \& Dima, 2010; Nicolescu \& Păun, 2009). Among the main recommendations should be mentioned the following: "to create a central department to deal in an integrative way with student experience, including all aspects of the students' life" and "to create regular data collection mechanism from various stakeholders - to monitor learning academic process and success by introducing student tracking practices; to regularly obtain feedback from the market .... the way they perceive the knowledge and skills of the graduates" (Nicolescu \& Dima, 2010, p. 107). These studies highlighted that there is a difference between the skills provided by curricula and the skills' importance at the workplace as perceived by students. It can be concluded that, on the one hand the university provides in term of skills very good theoretical scientific knowledge, adaptability and the ability to work independently and on the other hand, the skills useful at the workplace (classified by degree of importance) are: communication skills, adaptability, self-esteem and the ability to solve problems.

Internationalization of companies has resulted in the reduction of barriers to international trade and investment. In terms of skills, the expansion of internationalization lead the companies to rethink the managerial model in response to the development trends of competitors active on the market, especially multinational companies. Thus, today's companies aim at recruiting the best employees and seek the skills necessary to conduct international activities. "Multinational corporations conduct part of their business across national boundaries" and their existence is based on efficiency derived from setting certain activities in other countries in order to reduce the costs and to access the best resources in terms of employees, distribution and raw materials (Sawyer \& Sprinkle, 2003, p. 115). Some authors called internationalization of the companies as an "unavoidable trend, as well as an important move frequently leading to the failure or success" (Yu, et. al, 2005, p. 8).

This international trend sets frames in terms of high-performing teams, diversity and interpersonal skills. When it comes to high performing skills, some authors (Cheruvelil et al., 2014) have concluded that team communication skills and team solving problems are essential for obtaining good results for the developed projects. By combining these abilities in complex research teams (teams that usually generate 
knowledge, translate research into policy and engage effectively with the public), the management of the company/ institution will generate new high - performing collaborative research teams in order to gain more work productivity, profit for the company and well-being for society/environment.

\section{Methodology}

\section{Students' perception on achieved skills upon graduation}

The paper aims to analyze the results of 3-year statistic data from Trendence Graduate Barometer (Trendence Institute, 2013, 2014, 2015). Trendence is a European research institute specialized in employer branding, personal marketing and recruiting. Also, this institute provides information regarding students' perception on achieved skills upon graduation, analyzing collections of data from universities across Europe. The dynamics of collected data in years 2013-2015 is shown below:

Table 1. Survey participants in Trendence Graduate Barometer

\begin{tabular}{|l|r|r|r|r|r|r|}
\hline \multirow{2}{*}{\begin{tabular}{l} 
Number of survey participants - \\
\cline { 2 - 7 } graduates
\end{tabular}} & \multicolumn{3}{|c|}{ Europe } & \multicolumn{3}{c|}{ Romania } \\
\cline { 2 - 7 } & 317.617 & 301.949 & 281.749 & 11.652 & 7.376 & $\mathbf{2 0 1 4}$ \\
\hline
\end{tabular}

Source: Trendence Graduate Barometer - European edition years 2013, 2014, 2015.

Starting from the above information, this study aimed at structuring and synthesizing the data in order to analyze the dynamics of international competences gained by curricular or extracurricular activities in Romanian universities, as perceived by students. Also, the paper aimed to establish students' interest for international experience and internationally -oriented companies. In addition, the analysis of students' satisfaction with curriculum and international skills provided upon graduation will draw new directions for future investigations on the possible development of internationalized curriculum.

\section{Findings}

\section{Relevant soft skills on the labor market}

The dynamics of students' appreciation for soft skills gain by curricular/ extracurricular activities during their university program heads to the conclusion that soft skills needed for the labor market are appreciated to a high degree by students. Thus, more than $71 \%$ of Romanian respondents consider that responsibility, flexibility, ability to work under pressure and social competences are very relevant skills for obtaining a job. As it is shown in Table 2, Romanian students' expectations are similar to their European colleagues, more than $65 \%$ of European respondents finding that these soft skills are relevant for their future career.

Table 2. Relevant soft skills on the labor market

\begin{tabular}{|l|r|r|r|r|r|r|}
\hline \multirow{2}{*}{ Soft skills } & \multicolumn{3}{|c|}{ Europe } & \multicolumn{3}{c|}{ Romania } \\
\cline { 2 - 7 } & $\mathbf{2 0 1 3}$ & $\mathbf{2 0 1 4}$ & $\mathbf{2 0 1 5}$ & $\mathbf{2 0 1 3}$ & $\mathbf{2 0 1 4}$ & $\mathbf{2 0 1 5}$ \\
\hline Responsibility & $87 \%$ & $87.6 \%$ & $85 \%$ & $87.5 \%$ & $79.6 \%$ & $81.6 \%$ \\
\hline Flexibility & $80.2 \%$ & $78.5 \%$ & $77.8 \%$ & $83.2 \%$ & $77.4 \%$ & $75.8 \%$ \\
\hline Achievement and aspiration & $50.5 \%$ & $53.7 \%$ & $53 \%$ & $57.5 \%$ & $74.5 \%$ & $74.2 \%$ \\
\hline Ability to work under pressure & $68.8 \%$ & $65.3 \%$ & $65.3 \%$ & $76.9 \%$ & $71.1 \%$ & $72,2 \%$ \\
\hline Social competence & $75.7 \%$ & $74.9 \%$ & $75.1 \%$ & $79.7 \%$ & $71.1 \%$ & $71.3 \%$ \\
\hline
\end{tabular}




\section{Students' appreciation on provided skills}

When it comes to analyzing the dynamics of Romanian students' appreciation on provided skills (Table 3), the level of satisfaction falls from $59.1 \%$ in 2013 to $42.8 \%$ in 2015 , becoming closer to the European average, which was $45.2 \%$ in 2015 . This could be interpreted as a high demand for performance in term of professional and practical skills necessary for the labor market as will be seen in Table 6 .

Table 3. Appreciation on universities providing skills necessary for labor market

\begin{tabular}{|c|c|c|c|c|c|c|}
\hline \multirow[b]{2}{*}{$\begin{array}{l}\text { Appreciation of skills } \\
\text { provided by universities }\end{array}$} & \multicolumn{3}{|c|}{ Europe } & \multicolumn{3}{|c|}{ Romania } \\
\hline & 2013 & 2014 & 2015 & 2013 & 2014 & 2015 \\
\hline Agreement & $44.7 \%$ & $44.6 \%$ & $45.2 \%$ & $59.1 \%$ & $45.5 \%$ & $42.8 \%$ \\
\hline Disagreement & $21.7 \%$ & $23.3 \%$ & $23.9 \%$ & $14.4 \%$ & $15.2 \%$ & $20.7 \%$ \\
\hline No opinion & $33.3 \%$ & $32.1 \%$ & $30.9 \%$ & $26.5 \%$ & $39.3 \%$ & $36.5 \%$ \\
\hline
\end{tabular}

Source: Trendence Graduate Barometer - European edition years 2013, 2014, 2015.

\section{Students' work experience}

Previous work experience, and in particular, the international work experience achieved during university courses is very important and reduces the time for obtaining a job. The following data (Table 4) shows the dynamics of Romanian students involved in extracurricular activities. Romanian students are more active in achieving practical experience in recent years, exceeding the European average. Thus, practical implications related to social activities has grown from 43.1\% in 2013 to 60.3\% in 2015. Moreover, the number of students involved in work, study or voluntary activities in a foreign country has grown from $24.7 \%$ in 2013 to $39 \%$ in 2015, exceeding the European average of $31 \%$. The attractiveness for international experience is also connected to students' career priorities, as seen in Table 5. Romanian students also demonstrate an increased interest for gaining professional skills and soft skills during their studies. The data shows that Romanian students' involvement points to work experience in the field of study. Thus, the number of students with at least 3 months of experience in the domain of study has grown from $57.6 \%$ in 2013 to $60 \%$ in 2015.

Table 4. Students' work experience during university courses

\begin{tabular}{|l|r|r|r|r|r|r|}
\hline \multirow{2}{*}{$\begin{array}{l}\text { At least 3 months of } \\
\text { experience achieved already }\end{array}$} & \multicolumn{3}{|c|}{ Europe } & \multicolumn{3}{c|}{ Romania } \\
\cline { 2 - 6 } & $\mathbf{2 0 1 3}$ & $\mathbf{2 0 1 4}$ & $\mathbf{2 0 1 5}$ & $\mathbf{2 0 1 3}$ & $\mathbf{2 0 1 4}$ & $\mathbf{2 0 1 5}$ \\
\hline Social activities & $39.2 \%$ & $45 \%$ & $48 \%$ & $43.1 \%$ & $59.8 \%$ & $60.3 \%$ \\
\hline $\begin{array}{l}\text { Work experience unrelated to } \\
\text { field of study }\end{array}$ & $64.7 \%$ & $62.5 \%$ & $66 \%$ & $61,30 \%$ & $57.5 \%$ & $58.9 \%$ \\
\hline $\begin{array}{l}\text { Work experience related to field } \\
\text { of study }\end{array}$ & $57.4 \%$ & $57.5 \%$ & $57 \%$ & $57.6 \%$ & $59 \%$ & $60 \%$ \\
\hline $\begin{array}{l}\text { Work, study or voluntary } \\
\text { activities in a foreign country }\end{array}$ & $30.7 \%$ & $31 \%$ & $31.8 \%$ & $24.7 \%$ & $38 \%$ & $39 \%$ \\
\hline Political activities & $9.2 \%$ & $10 \%$ & $10.2 \%$ & $14.9 \%$ & $17.5 \%$ & $17 \%$ \\
\hline
\end{tabular}

Source: Trendence Graduate Barometer - European edition years 2013, 2014, 2015.

\section{Students' career priorities}

The dynamics of students' attractiveness for internationally oriented companies and their career priorities is shown in Table 5. Romanian students tend to accomplish strategic tasks rather than operational tasks upon graduation. In conjunction with their preference for multinational companies and general management responsibilities, this could be summarized as a choice for international skills needed for work in highperforming teams. The data shows that the respondents need more specialization in achieving their specific priorities. Thus, the number of Romanian students seeking to 
specialize upon graduation grows from 53.5\% of respondents' number in 2013 to $59.3 \%$ in 2015, exceeding the European average which was 54.3\% in 2015.

Table 5. Students' career priorities

\begin{tabular}{|c|c|c|c|c|c|c|}
\hline \multirow[b]{2}{*}{ Career priorities } & \multicolumn{3}{|c|}{ Europe } & \multicolumn{3}{|c|}{ Romania } \\
\hline & 2013 & 2014 & 2015 & 2013 & 2014 & 2015 \\
\hline Specializing & $53.9 \%$ & $53.8 \%$ & $54.3 \%$ & $53.5 \%$ & $56.3 \%$ & $59.3 \%$ \\
\hline Gaining general skills & $46.1 \%$ & $46.2 \%$ & $45,70 \%$ & $46.5 \%$ & $43.7 \%$ & $40.7 \%$ \\
\hline Graduate trainee program & $51.9 \%$ & $49.1 \%$ & $48.6 \%$ & $62.5 \%$ & $56 \%$ & $52.9 \%$ \\
\hline Direct entry & $48.1 \%$ & $50.9 \%$ & $51.4 \%$ & $37.5 \%$ & $43.9 \%$ & $47 \%$ \\
\hline Strategic tasks & $55.3 \%$ & $52.8 \%$ & $52.6 \%$ & $50.1 \%$ & $51.6 \%$ & $61.2 \%$ \\
\hline Operational tasks & $44.7 \%$ & $47.1 \%$ & $47.4 \%$ & $49.9 \%$ & $48.4 \%$ & $38.8 \%$ \\
\hline Temporary employment & $15.4 \%$ & $18.4 \%$ & $17.9 \%$ & $13.6 \%$ & $20 \%$ & $18.8 \%$ \\
\hline Permanent employment & $84.6 \%$ & $81.6 \%$ & $82.1 \%$ & $86.4 \%$ & $80 \%$ & $81.2 \%$ \\
\hline Multinational companies & $58 \%$ & $53.2 \%$ & $53.7 \%$ & $50.8 \%$ & $54.7 \%$ & $56.9 \%$ \\
\hline Small/ medium-sized enterprise & $42 \%$ & $46.7 \%$ & $46.3 \%$ & $49.2 \%$ & $45.2 \%$ & $43.1 \%$ \\
\hline Specialist position & $56.4 \%$ & $57.7 \%$ & $55.3 \%$ & $56.9 \%$ & $53.8 \%$ & $47.5 \%$ \\
\hline $\begin{array}{l}\text { General management } \\
\text { responsibilities }\end{array}$ & $43.6 \%$ & $42.4 \%$ & $44.6 \%$ & $43.2 \%$ & $46.2 \%$ & $52.5 \%$ \\
\hline
\end{tabular}

Data sources: Trendence Graduate Barometer 2013, 2014, 2015 - Romanian Business Edition.

\section{Students' perception of university performance}

In terms of importance versus satisfaction on university performance, the Romanian students appreciate the positive trend of Romanian universities in completing the internationalization process - Table 6 . More than $66 \%$ of respondents are content with the exchange programs and university partnership. Also, they appreciate universities' implication on social events, jobs and career fairs. The students perceive one weakness, the practical relevance of the content of the study. In dynamics, the students' appreciation shows a slow growth from $46.2 \%$ in 2013 to 56.6\% in 2015, under the European average: $62.9 \%$ of respondents' appreciation. On the other hand, the students consider that universities need to develop collaboration with private companies in order to integrate the theory with the work experience. Thus, the degree of satisfaction with the integrated work experience given by curricular and extracurricular activities falls from $70.6 \%$ in 2013 to $40.9 \%$ in 2015. In other European universities, the percent decreased from $69.6 \%$ in 2013 to $49.1 \%$ in 2015 . This data also highlights that there is a connection between curricula, international skills and future employability. Students tend to appreciate more the professional competence, the practical relevance of the content of study and the possibility to access international training programs during their university course.

Table 6. Students' perception of university performance

\begin{tabular}{|l|r|r|r|r|r|r|}
\hline \multirow{2}{*}{$\begin{array}{l}\text { Evaluation of university } \\
\text { performance: }\end{array}$} & \multicolumn{2}{|c|}{ Europe } & \multicolumn{3}{|c|}{ Romania } \\
\cline { 2 - 7 } & $\mathbf{2 0 1 3}$ & $\mathbf{2 0 1 4}$ & $\mathbf{2 0 1 5}$ & $\mathbf{2 0 1 3}$ & $\mathbf{2 0 1 4}$ & $\mathbf{2 0 1 5}$ \\
\hline Professional competence & $59 \%$ & $65.8 \%$ & $88.7 \%$ & $69.4 \%$ & $67.6 \%$ & $91.8 \%$ \\
\hline Importance & $69.8 \%$ & $70 \%$ & $83.7 \%$ & $68.2 \%$ & $71.7 \%$ & $81.4 \%$ \\
\hline Satisfaction & $56.4 \%$ & $53.3 \%$ & $76.8 \%$ & $73 \%$ & $54 \%$ & $76.6 \%$ \\
\hline $\begin{array}{l}\text { Practical relevance of the content of } \\
\text { study }\end{array}$ & $54 \%$ & $53.5 \%$ & $62.9 \%$ & $46.2 \%$ & $50.9 \%$ & $56.6 \%$ \\
\hline Importance &
\end{tabular}




\begin{tabular}{|c|c|c|c|c|c|c|}
\hline Integrated v & & & & & & \\
\hline Importance & $54.2 \%$ & $61.5 \%$ & $61.1 \%$ & $63.3 \%$ & $57.5 \%$ & $69 \%$ \\
\hline Satisfaction & $69.6 \%$ & $67.7 \%$ & $49.1 \%$ & $70.6 \%$ & $68.4 \%$ & $40.9 \%$ \\
\hline $\begin{array}{l}\text { Exchange pr } \\
\text { partnership }\end{array}$ & & & & & & \\
\hline Importance & $44.1 \%$ & $47.9 \%$ & $54.4 \%$ & $60 \%$ & $50.6 \%$ & $66.4 \%$ \\
\hline Satisfaction & $60.1 \%$ & $63.5 \%$ & $64.8 \%$ & $55.3 \%$ & $65.5 \%$ & $66.5 \%$ \\
\hline \begin{tabular}{|l|} 
Events \\
\end{tabular} & & & & & & \\
\hline Importance & $38.2 \%$ & $41.1 \%$ & $52.8 \%$ & $51.1 \%$ & $49.8 \%$ & $65.7 \%$ \\
\hline Satisfaction & $65.1 \%$ & $64.4 \%$ & $68.1 \%$ & $59 \%$ & $61.5 \%$ & $62 \%$ \\
\hline $\begin{array}{l}\text { Consultatio } \\
\text { job exchang }\end{array}$ & & & & & & \\
\hline Importance & $41.6 \%$ & $45.3 \%$ & $50.2 \%$ & $57.2 \%$ & $48.2 \%$ & $63.3 \%$ \\
\hline Satisfaction & $38.9 \%$ & $42.1 \%$ & $50.6 \%$ & $36.3 \%$ & $46.3 \%$ & $40.5 \%$ \\
\hline Jobs and car & & & & & & \\
\hline Importance & $48.7 \%$ & $48.1 \%$ & $49.2 \%$ & $56.3 \%$ & $43.8 \%$ & $63.2 \%$ \\
\hline Satisfaction & $52.7 \%$ & $52.8 \%$ & $56.7 \%$ & $43.7 \%$ & $48.5 \%$ & $53.5 \%$ \\
\hline
\end{tabular}

PICBE $\mid 520$

Source: Trendence Graduate Barometer - European edition years 2013, 2014, 2015.

\section{Conclusions}

Students' expectations regarding international competences have grown in recent years due to graduates' preference towards multinational companies.

The results of this paper came to confirm the opinion of Nicolescu \& Păun (2009) that universities provide very good theoretical knowledge and professional competences but there is still a need to improve the practical relevance of the content of study and the provided soft skills for the labor market.

Students' expectations are changing as the demands for labor force are changing. Since the demand for international competences has increased in recent years, a periodical change in curriculum is related to this new request of students and companies. Romanian students often appreciate the skills that ensure more access to the labor market. Skills like positive attitude, team solving problems, international communication, adaptability to work in a multinational environment, strategic view, flexibility and ability to work under pressure are considered very useful in finding a job upon graduation. These skills are also gained by work experience during university studies. Thus, students often choose to work, study or take part in voluntary activities in a foreign country or to develop social activities that provide the capacity to achieve international skills. Here, the universities have their role in developing an international relation with foreign universities and institutions to ensure better access for students to international internships. Since labor market has increased the demand for practical skills, students choose to gain work experience even if is not related to their field of study (more than 58\% of interviewed Romanian students work during their university studies).

Still, this paper does not provide factual information on specific needs for changes in the curricula. A possible comparison between the results of this study (focused on the students' perspective) and a future study focused on companies could bring more information on developing the internationalized curriculum. 


\section{References:}

Altbach P.G., Knight, J., (2007). The internationalization of Higher Education: Motivations and Realities, Journal Studies in International Education, 11(3/4), 290-305, DOI: 10.1177/1028315307303542.

Azim S., Gale A., Lawlor-Wright T., Kirkham R., Khan A., Alam, M., (2010). The Importance of Soft Skills in Complex Projects, International Journal of Managing PICBE | 521 Projects in Business, 3(3), 387-401.

Brooks, R., Waters, J. (2011). Students Mobilities, Migration and the Internationalization of Higher Education, Basingstoke: Palgrave Macmillian.

Cheruvelil K.S., Soranno P.A., Weathers K.C., Hanson P.C., Goring S.J., Filstrup C.T., Read, E.K., (2014). Creating and maintaining high-performing collaborative research teams: the importance of diversity and interpersonal skills, The ecological Society of America, 12(1), 31-38, DOI:10.1890/130001.

Enders, J and de Weert, E. (2009). Towards a T- shaped Profession: Academic Work and Career in the Knowledge Society, The Changing Face of Academic Life - Analytical and Comparative Perspectives, 251-271, Hampshire: Palgrave Macmillan

European Commission. (2014). Modernisation of Higher Education in Europe - Access, retention and employability 2014, Eurydice Report. Luxembourg: Publications Office of the European Union, 61-64.

European Commission/Youth (2014). ERASMUS+ Inclusion and Diversity Strategy -in the field of Youth. Retrieved from http://ec.europa.eu/assets/eac/youth/library/rep orts/inclusion-diversity-strategy_en.pdf.

Matthews, N., Green, P., Hall, D., Hall I. (2009). The role of Volunteering in Transistion from Higher Education to Work, Transitions from Education to Work New perspectives from Europe and Beyond, Basingstoke: Palgrave Macmillan.

Nicolescu L. (2011). Student experience in Romanian higher education - a comparative institutional approach, Transformations in Business \& Economics, 10(2B-23B), 664-684, ISSN 1648 - 4460.

Nicolescu L., Păun C., (2009). Relating higher education with the Labour Market: Graduates' expectations and employers' requirements, Tertiary Education and Management, 15(1), 17-33.

Nicolescu L., Dima A.M., (2010). The Quality of Educational Services - Institutional case Study from Romanian Higher Education, Transylvanian Review of Administrative Sciences. Retrieved from http://rtsa.ro/tras/index.php/tras/article/view/105/ 101.

Nicolescu L., Galalae C., (2013). A Systematic Literature Review On Students' International Mobility And Cultural Adjustment, Management \& Marketing Challenges for the Knowledge Society, 8(2), 261-282.

OECD, (2016). Global Competency for an Inclusive World, Retrieved from https://www.oecd.org/pisa/aboutpisa/Global-competency-for-an-inclusiveworld.pdf.

Ortega Goodspeed, T., (2016). Untangling the Soft Skills Conversation, The Dialogue Leadership for the Americas, CAF Development Bank of Latin America. Retrieved from http://1m1nttzpbhl3wbhhgahbu4ix.wpengine.netdna-cdn.com/wpcontent/uploads/2016/05/Soft-Skills-InDesign-English-v4.pdf. 
Oxford dictionary online, soft skills. Retrieved from https://en.oxforddictionaries.com/definition/soft_skills.

Robles M.M., (2012). Executive Perceptions of the Top 10 Soft Skills Needed in Today's Workplace, Business Communication Quarterly, 75(4), 453-465, DOI: $10.1177 / 1080569912460400$.

Sawyer W. C., Sprinkle R. L., (2003). International Economics, New Jersey: Pearson Education.

Stan S.O., Butum L.C., Zodieru A. (2016). New perspectives in developing the relationship between the university and the business environment in the light of the provisions of EU framework documents, Responsible entrepreneurship - vision, development and ethics: Proceedings of the 9th International Conference for Entrepreneurship, Innovation and Regional Development, Bucuresti: Comunicare.ro.

Trendence Graduate Barometer (2013). Retrieved from http://web.rau.ro/mydocumen ts/asociatiaabsolventilorura/2013-trendence\%20Graduate $\% 20$ Barometer $\% 20$ 2013\%20-\%20Romanian\%20Total\%20Edition_URA.pdf.

Trendence Graduate Barometer (2014). Retrieved from http://qa.ubbcluj.ro/documents/satisfactia_studentilor/esb_2014/Graduate_Bar ometer_2014_Romanian_Total_Edition.pdf.

Trendence Graduate Barometer (2015). National University of Political Studies and Public Administration.

Yu C-M. J., Guang J-L., Yang K-P., Chiao Y-C., (2005). Developing the skills for International Business, Journal of Teaching in International Business, 16(4), 5-26, DOI: 10.1300/J066v16n04_02. 